\title{
«Green» innovations in transport branch: restrictions, ways of implementation
}

\author{
Olga Podolyak ${ }^{1}$, Anastasia Akulova ${ }^{1, *}$, and Tatiana Mineeva ${ }^{1}$ \\ ${ }^{1}$ Mechanics and Machine Building Institute, Ural Federal University, Russia
}

\begin{abstract}
The course of "sustainable development" is relatively new to the Russian economy and its segments, however even now, experts believe that in the near future, the vast majority of innovations will be "green". The environmental and frugality problems are especially acute for the transport system of the country. The comparison with countries, having the most promising automotive industries, has shown that for developed automotive transport is characteristic developed infrastructure, accompanying vehicle at all stages of the life cycle. The authors consider the organization of the utilization market in the transport system of the country as one of the most promising directions in the transition to resource-saving technologies. The article describes the market mechanisms regulating the utilization market in Europe, reveals the barriers to organization of recycling in the Russian Federation. To overcome these barriers possible market mechanisms are suggested, i.e. the incentive of members of the transport system to create an organization chart of the utilization market. At this stage, a cluster scheme may be offered under which one the control and the responsibility belong to the automaker. This would allow reducing the cost of creating the infrastructure for the recycling system. Were formulated the possible positive effects for each of the participants of transport system. Were formulated the challenges for further research.
\end{abstract}

\section{Introduction}

Historical development of the cities, regions and countries is closely connected with the transport development. Addressing to a historical retrospective, it is possible to allocate some epoch throughout which the transport influence on the countries and regions development is most noticeable. The first stage can be considered the Middle Ages and Renaissance when the leading positions in the world belonged to the states having the best fleet. Thanks to the sea transport modern outlines of the world were open, the main trade ways were made, the first higher engineering schools were founded as a naval. The second stage is connected with development of the railroad. The railroad most influenced on the industry growth of the end of the 19th century. It is considered to be that the industrial revolution began with Great Britain where the first railroad was constructed, it is difficult to present a further way of industrialization without the railroad. The following stage is connected with emergence of an internal combustion engine and the invention of brothers Wright, for today it is possible to see that the countries with the developed automotive and aviation industry (Germany, the USA, Japan, etc.) have the steadiest and strong economy.

The modern civilization can't live without transport infrastructure, but overproduction results in need to solve a problem of outdated vehicles processing.

\footnotetext{
Corresponding author: aa.akulova@urfu.ru
}

The growth of the intractable waste is the natural tendency caused by economic development. The correct recycling not only protects the environment from pollution, but also is a source of raw materials which can be used again. It should be noted, that in the motor-car industry this problem is the most actual, for example, only during 2013 year the vehicle fleet in Russia grew more than by 5 million units [1]. The vehicle fleet growth steadily leads to:

- the ecological situation deterioration,

- the roads capacity reduction,

- the decrease in the level of the transportations safety.

Since the end of the 20th century the policy and researchers from different countries speak about the economy "sustainable development", directing the main efforts to resource-saving and minimization of negative consequences for environment. According to such approach to economic activity, the majority of innovations will be anyway directed on restoration and rational use of resources, improvement of an ecological situation and decrease in production sector influence on the ecological situation $[2,3]$.

One of the "steady" development concept approaches is the "return" logistics. The "return" logistics considers the material, financial and information streams movement from the final stage of a product life cycle to a new one (new life cycle). In many European countries the waste processing (recycling) systems successfully function, including the motor-car industry, which 
becomes a potential source of secondary resources and energy. For example, in the USA more than 20 million tons of cars are annually processed.

The first attempts on the cars utilization system creation are conducted now in Russia. Researchers and other interested persons are faced by some important tasks:

- development of an effective system of utilization state program with concrete factors and indicators;

- development of market and state mechanisms for stimulation the cars utilization;

- study of standards and legal questions of the utilizing companies activity

- etc.

The greatest interest is in creation of the economical and organizational scheme of the cars utilization market.

\section{The foreign experience in the market and state regulation of the recycling}

For many years in the European countries the recycling system for the consumption and production waste was formed, the first regulations (legislative act) appeared in Germany in the 17th century. The term recycling appeared in Germany by 60th years of the XX century. Recycling is the product processing, for the reusing. At the same time processing industry formation begins. Today, Germany has one of the most successful processing industries, therefore for forecasting of the car recycling market development in Russia it is useful to look through the experience of other countries. Feature of recycling systems of these countries is that they are part of the transport system, providing production, service and transport companies with secondary materials and energy resources.

The analysis results of the tools and measures for the utilization market regulation are presented in the Table 1 [4-9]. This tools and measures are widely use in different countries.Maintaining the Integrity of the Specifications.

Experience of foreign countries shows that at the first stages of the vehicles utilization market formation strong intervention of the state is necessary, because at the first period it is necessary to: stimulate producers:

- to use secondary raw materials;

- to create the provisions regulating activity of each participant of the utilization market and their responsibility.

In countries with well-developed automotive industry established recycling systems of vehicles that can recover about $80 \%$ of the weight of the car to secondary resources. Principles of construction, management and operation of systems are based on the existing economic structures, especially insurance and environmental legislation. Other conclusion which can be made according to the table is that the main market mechanisms are connected with development of encouragement and penalties, change of tax base and preferential crediting.

Table 1. The main measures used for the utilization market regulation in different countries.

\begin{tabular}{|c|c|c|}
\hline \multirow{2}{*}{$\begin{array}{l}\text { The } \\
\text { country }\end{array}$} & \multicolumn{2}{|l|}{ The regulation measures } \\
\hline & The economical & The legislative \\
\hline USA & $\begin{array}{l}\text { - private recycling } \\
\text { facilities, bred to self- } \\
\text { sufficiency; } \\
\text { - the high payment for the } \\
\text { waste disposal; } \\
\text { - the cost of processing is } \\
\text { lower, than the cost of } \\
\text { waste storage; } \\
\text { - low tariff rates on } \\
\text { transportation of the } \\
\text { secondary raw materials; } \\
\text { - existence of a large sales } \\
\text { market of spare parts from } \\
\text { the cars which have to be } \\
\text { utilize; } \\
\text { - the self-sufficient, private } \\
\text { utilization enterprises }\end{array}$ & $\begin{array}{l}\text { - the maintenance } \\
\text { minimum of the } \\
\text { secondary raw materials } \\
\text { in production is } \\
\text { established; } \\
\text { - waste disposal, made in } \\
\text { other states is forbidden; } \\
\text { - norms to quality of } \\
\text { secondary raw materials } \\
\text { are entered; } \\
\text { - research works on } \\
\text { elimination } \\
\text { technological of } \\
\text { economic barriers for the } \\
\text { secondary raw materials } \\
\text { using in production are } \\
\text { stimulated; }\end{array}$ \\
\hline $\mathrm{EU}$ & $\begin{array}{l}\text { - financing of industry due } \\
\text { to assignments of car } \\
\text { makers (importers), } \\
\text { - state grants; } \\
\text { - the raised tax rates for the } \\
\text { producers who are not } \\
\text { applying } \\
\text { resources; } \\
\text { - preferential crediting and } \\
\text { the taxation of the utilizing } \\
\text { enterprises; } \\
\text { - receiving considerable } \\
\text { part of the income from } \\
\text { sale of spare parts; } \\
\text { - the low tariff rates on } \\
\text { transportation of the } \\
\text { secondary raw materials; } \\
\text { - the pricing regulation in } \\
\text { the market of worn-out } \\
\text { tires; }\end{array}$ & $\begin{array}{l}\text { - fixing the responsibility } \\
\text { for utilization to the } \\
\text { manufacturing enterprise; } \\
\text { - uniform obligatory } \\
\text { marking of details is } \\
\text { entered; } \\
\text { - the instruction about } \\
\text { need to provide the } \\
\text { enterprises for utilization } \\
\text { with technological } \\
\text { documentation an on } \\
\text { dismantling and a } \\
\text { possible reuse of auto } \\
\text { components is approved; } \\
\text { - a ban on placement of } \\
\text { certain auto components } \\
\text { on the dumps; } \\
\text { - indicators of efficiency } \\
\text { and planned indicators of } \\
\text { work for the utilizing } \\
\text { industry are approved; }\end{array}$ \\
\hline Japan & $\begin{array}{l}\text { - use of } \begin{array}{r}\text { secondary } \\
\text { resources in various }\end{array} \\
\text { industries; } \\
\text { - granting workplaces at } \\
\text { the utilizing enterprises to } \\
\text { disabled people; } \\
\text { - the payment for } \\
\text { utilization of Freon in } \\
\text { conditioners, pyros in the } \\
\text { airbags, and also } \\
\text { operational liquids is } \\
\text { assigned to the cars } \\
\text { owners; }\end{array}$ & $\begin{array}{l}\text { - legislative stimulation } \\
\text { of producers to use the } \\
\text { secondary raw materials; } \\
\text { - standards of the } \\
\text { industrial wastes } \\
\text { processing are approved; } \\
\text { - the instruction to choose } \\
\text { easily utilized materials } \\
\text { for production, and also } \\
\text { to provide information } \\
\text { about the utilization } \\
\text { ways; }\end{array}$ \\
\hline
\end{tabular}

\section{The utilization market organizational scheme creation in Russia}

In the Russian Federation the issue of vehicles recycling doesn't have a long history and the starting point is considered the Federal Law "On Production and Consumption Waste" (from 24.06.1998 g). It should be noted that the law regulates the disposal in general, without specific reference to the automotive industry. The main activities described in the bill relate to environmental, while resource conservation is not considered at all. 
Since 2012 in Russia utilization charges are exist. These charges are paid by producers and importers of the cars, trucks and buses, also it is necessary to mention that the approved rates are one of the highest in the world practice. $[8,10]$ Thus, in two years of the law action in the budget considerable funds from the utilizing tax are saved, however they can't be used because in the country there is no infrastructure, standard and organizational support of the utilization market.

Today's situation can be presented in the following scheme (Figure 1). From this scheme it is visible that the logistic chain is not closed. So we can say that the principles of the return logistics are not carried out. Today enterprises engaged in recycling of vehicles and their waste in Russia, are not highly specialized and don't have common objectives, performance criteria and technological support. Most of the companies involved in the recycling of vehicles are engaged in the processing of ferrous and nonferrous metals, tires and batteries, and a significant proportion of non-metallic material is sent for disposal. Therefore, despite the presence in the market of individual companies providing utilization services vehicles, talk about recycling system inside the transport complex does not seem possible.

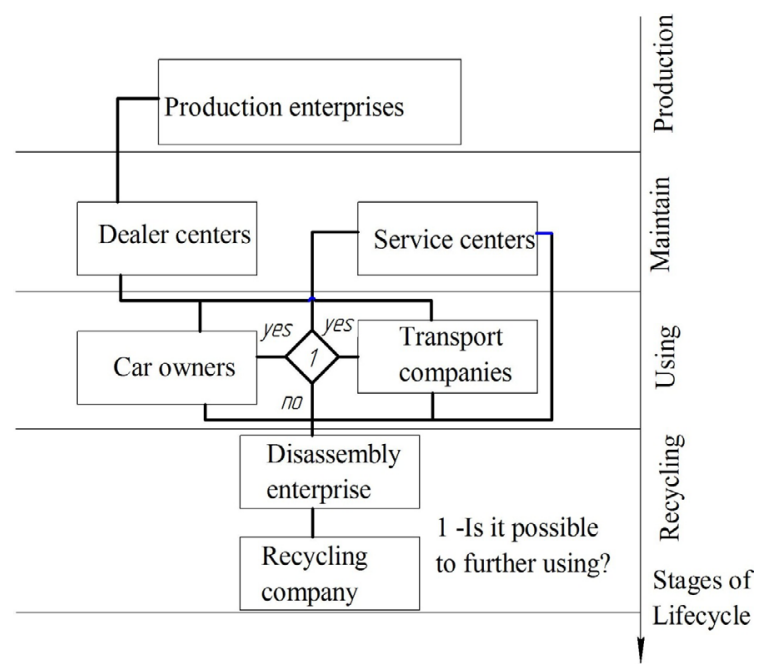

Fig. 1. The material stream movement scheme in automobile industry today.

The main objective of this organizational scheme consists in stimulating updating of vehicle fleet and the car sale made in the Russian territory. Such approach will not allow to gain the considerable ecological effect and to create the profitable industry of recycling. In the conditions of market economy in the country, only the utilization market can be successful, therefore, it has to possess three obligatory signs:

1. The private ownership,

2. The voluntary economic interaction of the independent subjects

3. The competition between the market players.

Functioning of the market is provided with various market mechanisms which main essence is to create the benefits for each participants. In that case when the market does not reach balance only by market mechanisms, state regulation is necessary. So, for the existing scheme it is necessary to provide market and state regulation mechanisms which would stimulate creation of the return material stream, thereby closing a logistic chain (Figure 2).

For today, it may be offered a cluster scheme under which one the control and the responsibility belong to the automakers. The cluster system is characterized by a close relationship between the recycling enterprises and the particular car manufacturer, which guarantees compliance of the recovery technological process, the return of valuable secondary materials automakers, allows to use of existing infrastructure service and dealer centers for receiving vehicles from their owners to shorten the path suitable for further use details. For the successful operation of the proposed scheme is necessary to conduct a series of events.

1. The private ownership,

2. The voluntary economic interaction of the independent subjects

3. The competition between the market players.

Functioning of the market is provided with various market mechanisms which main essence is to create the benefits for each participants. In that case when the market does not reach balance only by market mechanisms, state regulation is necessary. So, for the existing scheme it is necessary to provide market and state regulation mechanisms which would stimulate creation of the return material stream, thereby closing a logistic chain (Figure 2).

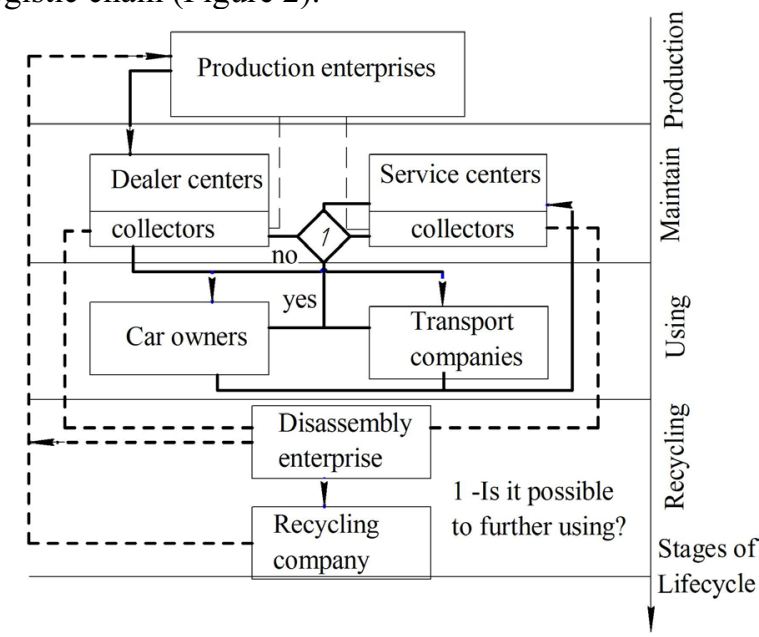

Fig. 2. The offered closed scheme of the material stream movement.

For today, it may be offered a cluster scheme under which one the control and the responsibility belong to the automakers. The cluster system is characterized by a close relationship between the recycling enterprises and the particular car manufacturer, which guarantees compliance of the recovery technological process, the return of valuable secondary materials automakers, allows to use of existing infrastructure service and dealer centers for receiving vehicles from their owners to shorten the path suitable for further use details. For the successful operation of the proposed scheme is necessary to conduct a series of events. 
First, it is offered to create the place points for end lifecycle vehicle (EVL) collecting with the dealer and service centers which received accreditation of the car producer. This activity will allow to create additional loading and workplaces for these companies.

Secondly, it is offered to enter various stimulation factors for using the secondary raw materials in the production, such as:

- development of the standards on quality and processing technology of the secondary materials;

- development of price policy for the secondary materials market;

- legislatively to fix the minimum percentage of secondary materials in production by industries.

Thirdly, the base for legitimate utilization activity creation is necessary. We have to take into consideration the secondary raw materials and services in utilization markets development. The utilization activity legislative act have to include establishment of the carrying out licensing process for the utilizing companies, development of the financial stimulation programs for the utilizing companies.

Taking into consideration the scale of the tasks arising when the utilization market is forming, the separate, specially created structure which is coordinating various subjects involved in formation process, performing analytical work and carrying out monitoring process has to be responsible for the result.

Formation of the car recycling market and waste utilization market in general is a necessary measure upon transition to "steady" development which demands the Practice shows that competitiveness of branch depends on a level of epy infrastructure development and ability to use potentials of still unused assets in the long term. Therefore for the Russian conditions it is necessary to develop and submit the functioning scheme of the vehicles utilization market which organically would fit into the existing transport complex and promoted its development.

Nowadays in Russia the first steps in organizational and economic regulation mechanisms development are taken, however, without the corresponding standard and legal base as well as without the infrastructure the recycling market cannot become independent and profitable.

\section{References}

1. State report "On the state and Environmental Protection of the Russian Federation in 2013". http://www.mnr.gov.ru/upload/iblock/6c7/ gosdokladeco.pdf

2. A state program of the Russian Federation "Energy saving and increase of power efficiency for the period till 2020”. http://government .ru/gov/results/13912/

3. GOST R ISO 14040-2010. Ecological management. Assessment of life cycle. Principles and structure. http://gostrf .com/norma_data/58/58831/index.htm

4. B.B. Bobovich, Vehicle scrappage and autocomponents (MGIU, Moscow, 2010)

5. T. Mikkonen, The Recycling of waste works, 6, 20$21(2009)$
6. I.S. Petrov, The Magazine of automobile engineers, 18-20 (2011)

7. R.L. Petrov, Magazine of automobile engineers, $\mathbf{1}$, 44-49 (2014)

8. R.L. Petrov, The Magazine of automobile engineers, 5, 52-57 (2012)

9. The directive of the European Parliament and Council 2000/53/EU 2000, belonging to the vehicles which served the term

10. Rules of collection, calculation, payment and collecting utilization collecting concerning wheel vehicles and the chassis, and also return and offset of excessively paid or excessively collected sums of this collecting. http://www .consultant.ru/document/cons doc LAW 161435/? Frame $=1$ 